\title{
THE KINDERGARTEN.
}

Ane Elizabeth Allen and Mary Howell.

THE following simple little story should explain its own use. It is one of the transient stories that seem to "make themselves" out of the necessity felt to bring before the children the ordinary household surroundings, inspiring in them a desire to verify, through their own observations at home, the correctness of each object with its use. The children supplied most of the story themselves, when it was once started, and showed more knowledge of this home industry than of the things that come closest to them. At the beginning of the year discouragement is often felt when little real interest is shown in any subject presented, but a little time devoted to the consideration of his own life seems to lay a foundation for any work that may follow for the child in this new life just beginning for him in the kindergarten.

\section{CORA'S WASH-DAY.}

ANAE ELIZABETH ALLEN.

"Everything seems so strange here," said little Cora. "Where am I ?" From over in one corner of the great room in which she was standing came a voice which said: "Come here, little girl, and I shall tell you where you are. You are in the land of the washing-day fairies, and I am their queen. You are the child who was sent to do the washing of the little people of my kingdom."

"Yes," said Cora, as she drew closer and closer to the kindlooking fairy, "so I've been told, but I see nothing to wash with." And she gave a frightened look at the pile of dainty fairy garments that lay at her feet.

"In fairyland," said the fairy queen, "that difficulty is easily overcome. Step on that small platform in the center of the floor, and call three times for everything you need, and use your ears. What do you need first?"

"I want three wash-tubs, just as there are in our laundry at home," said Cora, and, standing on the tiny platform, she called: "Tubs! tubs! tubs! where are you, tubs?" 
"Here we are, come and find us," came a chorus of little voices.

Cora followed the sound of the voices and soon found the tubs, and the fairies brought them out and put them in place for her.

"What next?" said the queen.

“Water! water! water! where are you, water?" Little Cora was on the platform calling, before the queen had finished asking.

"Here are the water drops ; here, come and find us."

So clear were the voices that Cora had no trouble whatever in finding them, and the water was soon pouring into the tubs.

"Soap! soap! soap! where are you, soap?" called Cora.

"Here we are, come and find us," came voices from some shelves in the corner.

"Wash-board! wash-board! wash-board! where are you?"

"Here I am, come and find me."

And now Cora was ready to begin her work. She tried to wring out the clothes with her little hands, when she remembered something she had seen used in her laundry at home that made the clothes so dry and was such fun to turn; and, standing again upon the little platform, she called: "Wringer! wringer! wringer! where are you?"

"Here I am, come and find me," was the reply from a little closet in a corner, from which the fairies brought the wringer.

Then Cora needed a basket, a stove, a boiler, some starch, and clothes-poles. The poles she found in the large backyard; the clothes line was sticking out of a hole in a bag and needed a great deal of pulling to bring out.

When everything was at last hung upon the line, the Wind, who had been watching his chance, caught up the clothes and, whirling them over and over, threw them down into the dirt.

Poor little Cora had forgotten one thing, and what do you suppose it was?

She gathered up the soiled clothes, rinsed them again, and, mounting the magic platform, called: "Clothes-pins! clothespins! clothes-pins! where are you, clothes-pins?"

"Here we are, come and find us. You forgot us, did you?" 
said they, as Cora took them from their hiding place; "what a pity!"

"Yes," said Cora, "but I shall never forget you again."

The sun shone warm and bright, and the mischievous wind blew and blew, and soon the clothes were ready to be sprinkled down, ironed, and put away. Cora called for ironing board, irons, iron holder, iron rest, and wax before she was ready to begin, and in the same magical way everything she needed was brought.

When the basket of dainty white garments was brought before the queen, she was greatly pleased, and to show her pleasure she called out all the little fairies of her kingdom, and in the light of the moon they danced, singing praises to the little girl from the work-a-day world who had done so well the work given her to do.

FIRST GRADE.

(FRANCIS W. PARKER SCHOOL.)

OUTLINE FOR OCTOBER AND NOVEMBER.

EDITH KINGMAN Hitz.

THE interests and activities of the children entering the first grade are so largely centered in the home and in animal and plant life that the plan for the work of October and November has been outlined with the special thought of meeting these interests and activities.

To encourage each child to do individual work, he should at once engage in some activity in which his interests are centered, for it is only when he is thus interested that he is willing to solve patiently the difficulties which arise before the completion of any piece of constructive work.

History.-The history work will begin with the construction of a playhouse which, when completed, will be given to the children of the kindergarten. A large dry-goods box will be used for the outer walls. The children themselves will decide on the best division of rooms, and, after putting in the partitions, will furnish and decorate. As the plan progresses, 